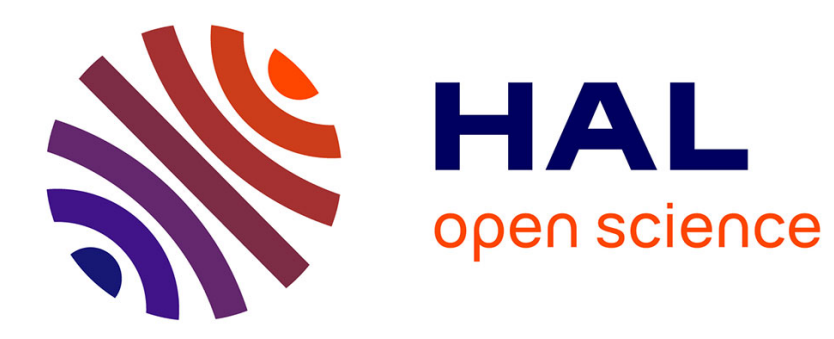

\title{
Rositsa T. Ilieva, 2016, Urban Food Planning: Seeds of Transition in the Global North
}

\author{
Kameshwari Pothukuchi
}

\section{To cite this version:}

Kameshwari Pothukuchi. Rositsa T. Ilieva, 2016, Urban Food Planning: Seeds of Transition in the Global North: London, New York: Routledge, 268 p. Review of Agricultural, Food and Environmental Studies, 2019, 100 (1-4), pp.145-148. 10.1007/s41130-019-00091-x . hal-03006586

\section{HAL Id: hal-03006586 https://hal.science/hal-03006586}

Submitted on 16 Nov 2020

HAL is a multi-disciplinary open access archive for the deposit and dissemination of scientific research documents, whether they are published or not. The documents may come from teaching and research institutions in France or abroad, or from public or private research centers.
L'archive ouverte pluridisciplinaire HAL, est destinée au dépôt et à la diffusion de documents scientifiques de niveau recherche, publiés ou non, émanant des établissements d'enseignement et de recherche français ou étrangers, des laboratoires publics ou privés. 


\title{
Rositsa T. Ilieva, 2016, Urban Food Planning: Seeds of Transition in the Global North
}

\section{London, New York: Routledge, 268 p}

\author{
Kameshwari Pothukuchi ${ }^{1}$
}

Published online: 11 November 2019

(C) INRA and Springer-Verlag France SAS, part of Springer Nature 2019

Home to a majority of the world's population, cities are more than simply places of food consumption. They also have the potential directly to influence other food system activities, such as production, distribution, and waste management. Indeed, over the last couple of decades, many cities are doing just this through food planning, while also advancing goals such as greater public and ecosystem health, social cohesion, and democratic participation. Food planning takes many forms: from food charters to comprehensive plans containing food system elements, to zoning and building codes that facilitate agriculture and access to healthy foods, to farm-to-institution projects, and more. It is also fostering new institutional spaces, such as food policy councils, boards and commissions, and mayoral task forces. Additionally, the growing number of books, journal issues, conferences, and professional groups focused on food planning attests to the accomplishments of, as well as interest in, this activity. Is food planning here to stay, as a durable driver of a set of sustainable alternatives to the global industrial food system? Has it become an integral part of formal governance processes within localities? These are key questions addressed by this ambitious and wide-ranging book by Rositsa Ilieva.

To answer the questions, Ilieva draws on transition theories, commonly introduced by an S-curve depicting an initial stage of pre-development followed by a period of rapid take-off, later leveling off as an established change. In assessing the nature of the challenge, if any, posed by urban food planning to the global industrial food system, her conclusion is a cautious one, I believe correctly so. At best, food planning reconfigures the global food system by fostering short, fair, and environmentally sound supply networks.

The book, though, is notable for more than this unsurprising conclusion. Along the way, Ilieva maps an impressive terrain that journeys through mostly familiar territory, though intermingled with less familiar developments from elsewhere in the global

Kameshwari Pothukuchi

k.pothukuchi@wayne.edu

1 Wayne State University, Detroit, MI, USA 
North as well as with new insights into historical material. These are reviewed briefly below. Familiar landmarks from North America include the San Francisco's Sustainability Plan, Toronto's Food Charter, and the American Planning Association's food planning Policy Guide - full disclosure: co-led by the late Jerry Kaufman, me, and Deanna Glosser - as well as the more recent but no less significant Milan Urban Food Policy Pact from Europe.

An introductory chapter outlines rationales for urban food planning; summarizes the many related intellectual, programmatic, policy, and organizational accomplishments since the turn of this century; and introduces theories of socio-technical transition against which urban food planning might be assessed as a system of innovations. Chapter 2 was particularly interesting for its extensive discussion of historical theories, of cities and city planning that integrate food system ideas and ideals, and analysis of the durability and limitations of these theories. Here, Ilieva revisits Ebenezer Howard's Garden City concept; Patrick Geddes's writings on the interdependence of cities and regions and his aspirations for citizens' roles in shaping cities; the Dutch RandstadGreen Heart Metropolis, which coordinated planning for town and country at multiple scales; and Frank Lloyd Wright's Broadacre City vision. Broadacre imagined universal landownership with ubiquitous food production in gardens, enabling not just household self-reliance but also sales of surplus to local outlets. Of course, few of these ideas, if they were implemented at all, retained intact the food system elements or goals envisioned, as Ilieva documents. Still, they constitute an undeniable intellectual heritage linking cities, planning, and food, and they continue to inspire new ideas and programs. This chapter also introduces newer visions such as Agronica, a hybrid urban space that incorporates agricultural production and suggests processes and technologies necessary to guide socio-technical transition, and Sitopia, in which author Carolyn Steele urges a view of cities through the lens of food and of food as a tool to remake cities. Thus, urban development and the agri-food system might be returned to interdependence to enhance the living environment and its long-term sustainability.

Chapter 3 offers many rationales for food planning-rationales related to the broken industrial food system and the promise of integrating foodscapes into urban environments, as well as to planning's strategic identification, sustainability mandates, the growing popularity of urban food planning, and the possibilities for advancing planning goals and for enhancing the profession's reputation. With examples from both sides of the Atlantic, this chapter describes common tools such as food policy guides, local food reports, land use decisions, research, advocacy, and design. Examples include preserving and expanding opportunities for regional and urban agriculture, institutional food procurement, community food assessment, land inventories and soil quality maps and urban agriculture plans.

Analytical tools and tactics to understand the city from a food planning lens are the topic of Chapter 4. It presents the varieties of assessments used to define and map diverse geographies of food procurement, their impacts on human and environmental wellbeing, and how planners may enable rather than hinder linkages. This chapter's inventories of community food assessments (p. 111-112) and sustainable food goals and indicators (p. 114-122) should be particularly useful to students and researchers. A subsequent chapter reviews the many activities within the public domain, such as food system policies, strategies, and plans, along with a useful discussion of food 
citizenship. Similar to food planning's transformative potential for urban planning in general, food citizenship can turn consumers into active and educated citizens and into co-producers as they create a food system that reflects collective goals and aspirations. In practice, of course, food planning is scarcely immune to the forms of class- and racebased exclusion that planning, as a whole, experiences. Nevertheless, here too, the inventories of urban, regional, and national food plans/strategies serve as a handy resource. Chapter 6 showcases select private-sector urban food system developments, including Wageningen University-led Agromere project in the Netherlands and Troy Gardens in Madison, Wisconsin.

Chapter 7's focus is on the political and institutional spaces in which food planning occurs. Food policy councils are by now a familiar forum that coalesces stakeholders from diverse sectors to set agendas and facilitate deliberations to inform collective action. Other spaces include planning departments, sustainability units, mayor's offices, and even multi-city policy networks such as those convened by the US Conference of Mayors, Sustainable Food Cities Network, the Urban School Food Alliance, the Community Food Security Coalition, and the Milan Urban Food Policy Pact. While these spaces are evidence of substantial success in organizing, resource mobilization, and political endorsement of food planning, they are also beset by common challenges, Ilieva acknowledges, such as lack of ongoing government support, paucity of resources, reliance on a small cadre of dedicated and skilled individuals, and political impotence.

In the final chapter, Ilieva returns to the questions at the top of this review, where she posits the socio-technical transition as oscillating between the pre-development and take-off phases. Assessing progress in the four domains of urban food planning experimentation - conceptual, analytical, design, organizational—she identifies areas where more capacity is needed. In sum, though, her main claims are well-supported: food is no longer a stranger to planners and political leaders in post-industrial cities; however, they are also limited in what they can do to realize sustainable food system goals. Although planners have played significant roles in all four domains of urban food planning activity, local planners still seem distant from grassroots programs, and the professional identity of food planners continues to be tenuous. Thus, despite many successes, few communities can claim to have institutionalized food planning that is comprehensive in scope and supported with law, resources, and professional expertise.

In sum, the book effectively organizes deep research of the scholarly and practice literature as well as of networks developed over the last couple of decades. Although I tend to agree with Ilieva's overall assessment about food planning's status as a sociotechnical innovation, I wish she had delved some more into the conditions responsible (or necessary) for successful institutionalization of food planning in a particular place or context, thereby updating similar such research (for example, Rocha 2001; Dahlberg 1994). The approach used in Chapter 2 might have served as a model for an analysis of the handful of city-regions that are leaders in food planning. Based on the selected criteria, what three or four Northern cities rise to the top, explained by what internal and external factors, and with what lessons for planning and food system scholarship and practice? Can a typology be created of regions that are in a state of readiness to realize progressively more of the goals embraced by food planning? Such gaps, however, take little away from the book's usefulness to students and scholars of cities, urban planning and politics, and agri-food systems. 


\section{References}

Dahlberg, K. (1994). Food policy councils: the experience of five cities and one county. Paper presented at the Joint meeting of the Agriculture, Food, and Human Values Society and the Society for the Study of Food and Society. Tucson, Arizona, 11 June.

Rocha, C. (2001). Urban food security policy: the case of Belo Horizonte, Brazil. Journal for the Study of Food and Society, 5(1), 36-47.

Publisher's note Springer Nature remains neutral with regard to jurisdictional claims in published maps and institutional affiliations. 